\title{
O Provérbio como Discurso de Dominação
}

\author{
Maria Lucia Mexias-Simon \\ Universidade Severino Sombra, Curso de Letras \\ Círculo Fluminense de Estudos Filológicos e Linguísticos \\ mmexiassimon@yahoo.com.br
}

\begin{abstract}
Resumo: Sendo a língua dinâmica e mutante, os provérbios permanecem em sua forma arcaizada que lhes dá o aval da tradição. Encontram-se semelhanças fônicas. morfo-sintáticas e lexicais entre as frases feitas em diversas linguas. São os provérbios ainda semelhantes quanto à preferência por determinadas esferas semânticas e quanto a seu emprego na manutenção do estabelecido.
\end{abstract}

Palavras-chave: Lexicologia. Locuções populares. Campos semanticos

\section{Proverbes Pour la Domination des Gens}

\begin{abstract}
Resumé: La langue étant dynamique et changeable, les proverbes restent en leur forme archaisée, qui leur donne l'aval de tradition. Qn trouve des ressemblances phonétiques, morpho-syntatiques el lexicales entre les phrases faites en plusieurs langues. Les proverbes sont, en outre. semblables pour determinés secteurs sémantiques et quant à leur emploi dans la manutention de l'établi.
\end{abstract}

Mots-clé: Lexicologie, locutions populaires, champs sémantiques

\section{Introdução}

Os chamados ditos populares existem em quase todas as línguas naturais. Isso pode ser comprovado peia existência de inúmeras de suas coletâneas, em distantes idiomas, no tempo e no espaço. Alguns povos são notoriamente mais produtivos nesse setor, como por exemplo, os chineses Os filólogos encontram na fraseologia popular elementos de estudo. Em forma concisa, de sonoridade agradável, ela guarda sobrevivências históricas, idiomáticas e sociais. Permite-nos acompanhar a história da humanidade e de cada povo. São as maneiras de falar "uma expressão constituida pela união de várias palavras, formando uma unidade sintática e lexicológica ${ }^{1}$ Distinguem-se das locuções prepositivas e conjuntivas; formando torneios idiomatológicos; estão à margem do uso normal da língua por suas características de forma e de som, pelo afastamento das normas lexicais e gramaticais e por seus valores metafóricos particulares, como se verá no decorrer do presente trabalho.

São signos arbitrários, porque a imagem que está na sua origem tende a se obscurecer, como de resto, em todos os signos linguísticos 
Na tentativa de análise da motivação inicial, a locução é rebelde, na maioria dos casos, a qualquer estudo histórico. A língua é sem dúvida o espelho do povo. Mas, se formos procurar atrás de cada palavra uma causa externa e material pode-se acabar por falsear os fatos A língua é um produto da história, do meio, as causas históricas de origem dos fatos linguísticos são numerosas, porém, uma minoria de fatos, baseados na forma própria, da língua, são os mais característicos e, portanto, os mais interessantes do ponto de vista linguístico. Isso se ajusta às locuções estereotipadas. É, por conseguinte, difícil e perigoso procurar saber a etimologia das frases que retemos de memória e aplicamos em diversas circunstâncias:

- Amor com amor se paga

- Devagar se vai ao longe

. Petit à petit, 1'oiseau fait son nid

Inclusive a fraseologia registrada em obras literárias ou religiosas não nos tira a dúvida, se tais expressões foram recolhidas e registradas pelos autores e compiladores dessas obras, ou se o povo as adota porque viu nelas aplicações para a vida prática. O seu aspecto arcaizado, na construção e no léxico, constitui exatamente o seu aval. O povo acredita nelas, pois são assim repetidas há várias gerações. Não importa que assentem em bases falsas:

- Martes, ni te cases, ni te embarques

. En martes, ni tela urdas, ni hija cases

O conceito de martes como dia aziago viria da derrota sofrida por valencianos e aragoneses nos campos de Luxón em 1276, ou de ser o dia consagrado ao deus da guerra?

Também a moral das fábulas pode ter sido adotada como dito popular, como podem ser as fábulas paráfrases de ditos já existentes.

A origem mais remota da fraseologia popular encontra-se nos velhos berços da civilização, na China tradicional, no Egito. na Índia e na Pérsia, até a civilização greco-romana, na Bíblia,. nas subsequentes obras inspiradas pelo Cristianismo, sobretudo no livro conhecido como Imitação de $\underline{\text { Cristo. }}$.

Já em Protágoras, afirma Platão; "a maneira dos antigos sábios era caracterizada por uma espécie de concisão lacônica...sentenças concisas e dignas de memória... máximas que estão em todas as bocas ${ }^{2}$

Como o folclore universal remonta sempre às mais recuadas fontes do passado, vai (a fraseologia popular - parênteses nossos) prender-se em última análise, geralmente à letra dos livros sagrados. Não raro, a fábula ou o conto, cuja manifestação moderna nos parece original, emigrou de papiros egípcios... nasceu no Zend-Avesta veio dos Puranas ou dos Vedas. Tanto quanto esses livros santos, a Bíblia não podia deixar de ser também fonte abundante de folclore quer repetindo temas já citados em outros repositórios, quer dando em primeira mão fatos novos e quer sendo origem de dizeres modificados ao saber popular. $^{3}$ 
O uso das locuções extraídas das obras literárias e dos livros religiosos é variável segundo o meio, o grau de instrução, os hábitos individuais. O latim medieval foi o meio de transmissão dessa herança antiga Nos romances, os ditos populares aumentam em número de variantes, com tendência a diminuir em tamanho. Alguns conservaram-se em latim:

. Sic transit gloria mundi

. In vino ventas

Na Idade Média já quase não se criaram expressões populares, mas conservaramse e transmitiram-se "entre os que iam e vinham da feira e os que faziam paradas em pousadas e hospedarias" " No autoritarismo e no conservadorismo da Idade Média, encontraram os ditos dos mais autorizados pela idade e pela cultura terreno favorável à sua permanência.

Excetuam-se do caráter de dito popular as frases que foram a propósito forjadas para serem gravadas e lidas pelos educandos ou para exteriorização de sentimentos:

. Nem cora o livro de ombrear com o sabre, nem cora o sabre de chamá-lo irmão. ${ }^{5}$

. N'insultez jamais une femme qui tombe. ${ }^{6}$

Excetuam-se também aquelas que, verdadeiramente ou não, foram proferidas por personagens de destaque em circunstâncias históricas:

. Vim. vi, venci.

. Tudo como dantes, no quartel-general d 'Abrantes.

. L'état c'est moi!

Não serão aqui tratadas, também, as frases, embora do domínio popular, constantes em livros sagrados, pois estas tem seu espaço próprio e também por falta de edições confiáveis

A utilização dos ditos populares na literatura é prática usual, desde a Antiguidade, sendo muito mais frequente na literatura dramática. Encontram-se em Gil Vicente, Camões. Shakespeare; Alfredo Cunha baseia-se em pesquisa de estudiosos para garantir-nos que nas peças Eufrosina e Ulyssipo de Jorge Ferreira de Vasconcellos encontram-se respectivamente mais de 600 e mais de $500 \underline{\text { ditos }}^{7}$. (grifo nosso).

A esse respeito, encontramos na Dissertação de Flora de Paoli Faria sobre Gtovani Verga:

\footnotetext{
A leitura dos textos enfatiza a importância da cultura popular como manancial ao qual se deve recorrer na busca de motivos autênticos, originais... Muitas são as definições atribuídas ao termo 'folclore'. Dentre elas, por exemplo, a possibilidade de reconhecer o folclore como a expressão exclusiva das classes mais humildes. Ela se opõe ao parecer de pesquisadores alemães que afirmam ser o folclore pertinente a iodas as classes sociais... Os conflitos inerentes à conceituação do âmbito folclórico se extinguem, quando entendemos que todos
} 
os aspectos do folclore são expressões de uma única força produtora, assinalada peia coletividade humana em seu continuo movimento de conservação e desenvolvimento... O estudo do conjunto folclórico permite a percepção de vários ritos usados pelo homem para orientar-se em sua caminhada em busca do conhecimento... A utilização de provérbios é uma constante... na produção de Verga não sendo utilizado unicamente como uma curiosidade folclórica ou dialetal. Os provérbios servem para destacar o peso da tradição popular no contexto regional. ${ }^{8}$

O que aqui se atribui a Giovani Verga, pode-se dizer da literatura em geral. O emprego da fraseologia estereotipada na literatura caracteriza um personagem, uma coletividade, uma região. Se bem que se encontram fórmulas de âmbito quase universal, surpreendentemente. O popular -- Time is money - que tanto nos parece caracterizar o moderno pragmatismo norte-americano, encontra equivalente na coletânea do Pe. António Delicado, em 1651 Perdendo tempo não se ganha dinheiro. ${ }^{9}$

Johan Huizinga estabelece estreita interligação cultural entre palavras como conselho, enigma, mito, lenda, provérbio, etc. Vejam-se as relações etimológicas entre os termos:

\begin{tabular}{|c|c|c|}
\hline Alemão & Holandês & Português \\
\hline Rätsel & Raadsel & enigma \\
\hline Rat & Raad & conselho \\
\hline erraten & --- & adivinhar \\
\hline raten & raden & aconselhar, adivinhar \\
\hline
\end{tabular}

Também em grego existem afinidades entre aívos (sentença, provérbios) e aítvı $\mu \alpha$ (enigma). Podemos concluir que originariamente o enigma era um jogo sagrado, e por isso se encontrava para além de toda distinção possível entre o Jogo e a seriedade Clearco, um dos discípulos de Aristóleles, escreveu um tratado sobre os provérbios, o qual encerrava uma teoria dos enigmas, provando que, originariamente, o enigma fora um assunto filosófico... A própria palavra problema, 'aquilo que é colocado diante de alguém' aponta para o desafio como origem da proposição filosófica... o filósofo... assumiu todas as características de um campeão."10

Os termos provérbio, problema, profecia, pertencem ao campo do jogo social, sendo o provérbio a regra desse jogo. Huizinga ainda inclui no jogo a figura do vates, originariamente, o possesso, inspirado por Deus, em transe e, mais tarde,

O poeta-vidente (que) vai gradualmente assumindo as figuras do profeta, do sacerdote, do adivinho... e do profeta tal como o conhecemos. O eterno abismo entre o ser e a ideia só pode ser franqueado pelo arco-íris da imaginação: Os conceitos, prisioneiros das palavras, são sempre inadequados em relação à torrente da vida; portanto, é apenas a palavra-imagem, a palavra figurativa que é capaz de dar expressão às coisas e. ao mesmo tempo, banhá-las com a luminosidade das idéias; ideia e coisa são unidas na imagem... Elementos como rima e o dístico só adquirem sentido dentro das estruturas... de que derivam: golpe e contragolpe, ascensão e queda, pergunta e resposta, numa palavra, ritmo. ${ }^{11}$ 
Ai estaria a raiz dos provérbios, objeto do presente estudo.

Trataremos, aqui, da dificuldade em batizar a locução estereotipada que faz parte do repertório léxico de um povo, ou de vários povos, face ao grande número de denominações.

A partir dos exemplos coletados, mostraremos como as locuções populares legislam nos diversos aspectos vida humana. Aqui deixamos em aberto a questão: Provérbios são feitos pelo povo ou para o povo? Partem das massas, destinam-se a elas e à juventude, isto é, aqueles que devem ser doutrinados?

E de se registrar uma grande deficiência para esse estudo, que é a quase inexistência de material autêntico de coleta de provérbios na linguagem falada Nesse setor. temos conhecimento apenas de um estudo realizado por K Daniels na Escola Superior de Pedagogia de Bonn; ${ }^{12}$ comprovou-se que as crianças (a idade não é mencionada) identificam de imediato os provérbios como tais; sabem que esses são empregados na comunicação, quando o falante quer dar validade à sua argumentação, não são verdadeiros em si, até porque os há contraditórios e porque o mundo mudou profundamente.

. Mais vale um pássaro na mão que dois a voar

. Quem não arrisca não petisca

. Gordura é formosura

A experiência teve como objetivo fazer com que os alunos se distanciem da autoridade do provérbio e reconheçam que esses são usados num determinado contexto, com um determinado objetivo. Porém, aqui se trabalhou com material recolhido com finalidade didática especifica.

No Brasil, realizou-se experiência, em 1977, por alunos da 5a série da Escola Alencastro Guimarães, no Rio de Janeiro. Os alunos solicitaram a pessoas que estavam em uma feira, que lhes dessem exemplos de provérbios. Os informantes são, em maioria, mulheres nordestinas, com primário completo. Alguns exemplos colhidos:

- Águas passadas não movem engenho

- Cré com cré e Cupumãm (sic) com chaminé

- Quem muitas pedras bole, uma lhe dá na cabeça

- Pra baixo todo santo ajuda, pra cima a coisa toda muda

. Você vai ver com quantos paus se faz uma cangalha. ${ }^{13}$,

As frases apresentadas no presente trabalho foram extraídas das coletâneas citadas na bibliografia e, algumas, da observação pessoal. Por ser um trabalho de Filologia Românica, consideramos as três línguas românicas com maior número de falantes: português, francês e espanhol (a sequência não corresponde ao número de falantes), mostrando que as características a serem assinaladas encontram-se frequentemente, em provérbios examinados nessas três línguas. Por razões óbvias, é em português apresentado o maior número de exemplos. 
Concordamos com Algirdas Julien Greimas ${ }^{14}$ que o conjunto de provérbios e ditados em dado tempo e lugar constitui um sistema de significação fechado com estatuto formal autônomo que leva a postular, por hipótese, a existência de um domínio semântico independente. $\mathrm{O}$ seu estudo explicaria alguns problemas de estilística e contribuiria para o estudo do simbolismo coletivo: mitos, sonhos, folclore.

\section{O Problema da Terminologia}

"E por isso dizia Aristóteles (como disse) que dos ditos aos sábios não se pede razão, porque vêem as verdades claramente e estes ditos chama Gnomas, cuja parte é o Refrão"15

Um dos mais difíceis problemas de terminologia está nos ditos populares. Muitas são as denominações e tentam os estudiosos fazer distinções entre elas, continuando os falantes a confundi-las. Seguem-se algumas dessas classificações, conforme as consideraram alguns dos autores consultados.

Segundo Ladislau Batalha, o provérbio apresenta em geral o aspecto de uma frase clássica, de forma mais ou menos literária, com ou sem rima, muitas vezes oriunda dos textos canônicos, “... a generalização oral de certos pensamentos... colhidos nas obras dos antigos filósofos gregos, romanos e outros, no Velho e no Novo Testamento e nos escritores clássicos,..${ }^{16}$, ao passo que os anexins. adágios e dizeres são colhidos da tradição oral popular, são folclóricos.

No século XV, com a influência espanhola generalizou-se entre nós o vocábulo - rifão -, aportuguesamento de Refran castelhano. (Refrão guarda ainda o sentido de estribilho, enquanto rifão, forma variante, tem apenas o sentido aproximado de ditado - parênteses nossos). A nossa mais antiga denominação era - anexim - donde modernamente se derivou anexirismo. O vocábulo - adágio-só veio a entrar em uso nos séculos imediatos para indicar o que os franceses até o século XII denominavam primeiro respit e, depois, reprouvier. ${ }^{17}$

Jürgen Schmidt-Radefeldt afirma serem os provérbios textos mínimos; podem ser reagrupados em ordem alfabética, classificados tematicamente; apresentam na sua estrutura características semânticas e sintáticas semelhantes uns aos outros. Distinguemse de outros textos mínimos, pois são anônimos, pertencem a uma comunidade linguística para cujo saber comum servem de veiculo de transmissão Não se confundem como as geflügelte Worte (citação muito frequente, como: ou sont les neiges d'antan; verde, que te quero verde; por mares nunca dantes navegados) pois essas tem autor conhecido.

Distinguem-se ainda dos apotegmas ou sentenças, que possuem fundamento científico ou filosófico.

Fernando Ribeiro de Mello não faz distinção na terminologia. Embora chame sua coletânea de Recolha de provérbios e outros lugares comuns portugueses, diz ser toda expressão popular uma "estrutura frásica, decorada, fossilizada e envelhecida." Mais adiante usa o termo anexim que seria a expressão anônima, sendo as outras formas atingidas pelos anexins e vice-versa. ${ }^{18}$ 
Luiz de Hoyos Sainz e Nieves de Hoyos Sancho preferem o nome refrão a parêmia. Embora seja paremiologia o nome do estudo cientifico da fraseologia estereotipada. Seria mais acertado chamar a esse estudo paremiografia. pois o estudo dos refrães é quase sempre uma coletânea, sendo a ordenação preferida, a alfabética, como nos dicionários comuns. Antes do século XV, usavam-se denominações que atualmente desapareceram fabla. fablilha. retraire, escritura, palavra, verbo. Hoje, prefere-se o termo refrão que se confunde com ditado, sentença, aforismo, máxima, apotegma, adágio, provérbio. Os dicionários remetem uns aos outros. Esses autores citam José Maria Sbardi y Osuna: "o dito, ou é vulgar ou não; o primeiro toma o nome de refrão; o segundo, adágio ou provérbio... o refrão tem um sentido jocoso... e é, por vezes, um simples sonsonete; o adágio... a madurez e a gravidade... o provérbio é natural e simples, tendo um critério histórico." 19

Alfredo Cunha estabelece distinção entre ditames e ditérios: aqueles seriam judiciosos e esses anexins de mofa e escárneo. Cita ainda outras denominações, selecionadas por outros autores:

\footnotetext{
Dr, Sousa Viterbo recolheu muitos adágios antigos nos Materiais para o estudo da Paremiologia portuguesa e nos Subsidios para a formação do refraneiro ou adagiário português (Porto, 190!), notando que o Sr. Dr José Leite de Vasconcellos emprega de preferência o termo adagiáno. e o Dr. Theophilo Braga adoptou a palavra refraneiro: entende que o derivado natural, posto que menos eufônico, de rifão, seria rifoneiro. Certo é, porém, que este vocábulo ainda não entrou nos dicionários da nossa língua, o que não impediu o Sr. Dr. Pedro Chaves de o dar recentemente como titulo á... compilação... $\underline{\text { Rifoneiro }}$ português. (Porto, 1928) ${ }^{20}$
}

Para Algirdas Julien Greimas, nas lexias textuais formadas por frases completas ou incompletas, os elementos serão conotativos, cada um por si ou não. O provérbio é conotativo.

- Quem semeia ventos colhe tempestades

. O sol nasceu para todos

. Bonjour lunettes, adieu fílletes

O ditado é formado de elementos não conotativos, cada um por si, isto é, não é necessário procurar sua significação:

\section{- Quem mente uma vez, mente sempre}

- Chose promise, chose due

Jacques Pineaux diz ter a palavra provérbio aparecido peia primeira vez nos textos do século XII, mas até o século XI11, prevalece na França o nome respit ou resprit.O termo ditado (dicton) data do século XI. Cita o abade Prévost, quando define ditado: “o provérbio, máxima ou sentença, curta e sensata, fundada ordinariamente sobre a experiência e capaz de instruir ou de corrigir." 21 Cita Le dictionnaire de l'Académie ao definir provérbio: "espécie de sentença, de máxima expressa em poucas palavras e tornada comum e vulgar." Jacques Pineaux, ele próprio, define: "provérbio é uma forma nitidamente cunhada de forma geralmente metafórica, pela qual a sabedoria popular exprime sua experiência de 
vida." ${ }^{22}$ Faz nítida diferença entre provérbio e expressão proverbial O provérbio oferece um conselho prático, enquanto a expressão proverbial descreve, segundo os usos da época, uma homem ou uma coisa.

- Esperto como a raposa,

- Sabido como mulher velha, (exemplos nossos)

Diz serem os provérbios mais abstratos que os ditados, por isso menos numerosos. Os provérbios exigem um esforço de abstração e de reflexão. Se se contar uma história mais ou menos longa a uma pessoa pouco afeita ao trabalho intelectual e terminar por um provérbio que a contradiga, terá a aprovação do ouvinte. O gosto da generalização esvai-se diante do esforço. Aires da Mata Machado Filho afirma ser "o adágio (predominantemente) moral, o rifão sentencioso e o provérbio público" (sic $)^{23}$

Diz ter Erasmo estabelecido em dois os requisitos do provérbio: vulgaridade e ausência de ambiguidade.

Já, segundo ainda Mata Machado, o adágio seria extraído dos oráculos, dos escritos dos sábios ou dos versos dos poetas, dai ser menos conhecido do povo (adágio < adagěre). Ninguém certamente chama as frases da Bíblia e dos clássicos, rifão, adágio ou anexim. Esse último termo é de origem árabe, com significado de copla. ${ }^{24} \mathrm{~A}$ palavra provérbio (do latim proverbium em vez do verbo) designa uma perífrase ou rodeio ao qual se recorre em lugar do termo próprio. Citando Amadeu Amaral em As tradições caipiras, diz que. desde o século XII, o termo provérbio tem suplantado os demais graças à influência da versão francesa da Bíblia Esta seria a prática de muitos atuais eruditos,

Bernard Pottier conceitua provérbio. "fórmula completa que traduz uma verdade geral e tradicional... sobretudo utilizado na língua falada... Tem um peso histórico, tem necessidade de uma certa antiguidade para se instalar na língua; donde seu aspecto frequentemente arcaico no que concerne à sintaxe ou mesmo à semântica"25

É muito difícil estabelecer uma concordância entre as diversas conceituações. Consente-se no aspecto moral do adágio, porém não se deixa de remetê-lo aos outros termos. $\mathrm{O}$ termo anexim, que seria o mais divulgado anteriormente, baixou no seu status, aproximando-se de ditério, ganhou um tom de sátira. Já a denominação apotegma distingue-se das demais por ter autor conhecido, ou, pelo menos, identificável, embora muitos possam repeti-lo sem saber identificar o autor.

Os termos apotegma, sentença e máxima têm mais afinidade entre si que com os demais termos. Expressam opiniões, conselhos, juizos a respeito da conduta humana. Podem até ser reunidos em coletâneas, por autor, (por exemplo, Máximas de la Rochefoucauld). O limite entre um conceito e outro é muito tênue, por vezes imperceptível, se não inexistente. Aforismo é mais aplicável às ciências, mas não proibido em outros contextos. $\mathrm{O}$ termo brocardo, do direito canônico estendeu-se ao campo jurídico em geral, daí sendo tomado como similar das demais denominações. Chufa é uma simples onomatopéia, que ganhou sentido aproximado a ditério, o conselho, a comparação, o julgamento trocista, registrado como brasileirismo, mais usual no sul; chufa é acompanhado ou introduzido pelo verbo correspondente chufar. 
Os termos dito. dizer, ditado, soam como neutros, isto é, substituem os demais em vários contextos com a ressalva de que dizer, mais comumente no plural dizeres, usa-se em geral, para algo que já está escrito (por exemplo, numa lápide). Gnoma, menos usado que os seus afins, reveste-se de um valor-verdade, embora menos forte que o axioma Esse é indiscutível, não carece de demonstração, está presente no campo das ciências exatas. (Antonio de Moraes Silva coloca aforismo no campo da física, Caldas Aulete em qualquer ciência, Aurélio Buarque de Holanda, no campo da moral). O verbete provérbio é de definição mais completa, enquanto alguns dos demais pouco além apresentam que remissões, uns aos outros Tem-se como estabelecido que as lexias textuais de caráter judicioso, extraídas da Bíblia, serão chamadas provérbios e não receberão nenhuma das outras denominações. Outro ponto comum é quanto ao aspecto da gravidade do provérbio; é um aconselhamento ou um juizo que pode ser repetido pelos eruditos, pela classe elevada, enquanto que, ao menos numa visão sincrônica, os ditérios, os anexins, as chufas ficam com as crianças ou a classe menos elevada. Destaca-se também, o valor alegórico do provérbio, esse seria o seu traço distintivo em relação ao ditado que não seria conotativo, segundo alguns autores, podendo ser entendido por membros de uma comunidade distante linguística e geograficamente

Parêmia pela menção ao aspecto alegórico é o termo próximo a provérbio. Quanto a refrão e rifão, . embora apontados como formas variantes entre si, para o primeiro vale também o sinônimo estribilho, que não vale para o segundo. São termos de entrada remota na língua, sendo as coletâneas,com os nomes refraneiro ou rifoneiro (assim como adagiário), usualmente denominadas.

Os dicionários etimológicos confirmam a formação onomatopaica de chufa; concordam na origem e no aspecto jurídico do termo brocardo. Para ditado encontramos em António Geraldo da Cunha, o curioso sentido de titulo nobiliárquico, assinalado também por Antonio de Moraes Silva, Conquanto os paremiologistas citados apontem a formação das palavras provérbio (pro-verbum ) e adágio (ad-agere), os dicionários etimológicos não o fazem: o processo de formação já ocorrera no latim. Antenor Nascentes relaciona

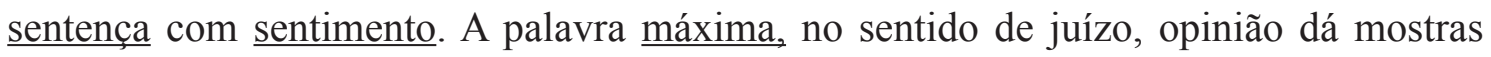
de ter-se destacado da expressão sentença máxima. Assinala-se ainda, a etimologia que António Geraldo da Cunha apresenta para refrão, acompanhando-a até o latim frangěre (quebrar, romper, modular).

Realmente, o estribilho na música ou na poesia, assim como o provérbio na argumentação, quebram a linha melódica. Ainda de acordo com Antonio Geraldo da Cunha a palavra provérbio é de registro bem recente em textos portugueses, embora seja de elevada frequência, de conhecimento de grande número de falantes da língua portuguesa.

Por esse motivo, foi provérbio o termo escolhido para denominação de nosso trabalho e em cujo decorrer será empregado mais frequentemente, já que a distinção entre esse termo e outros é teórica. Para as coletâneas, será dada preferência à denominação paremiologia. uma vez que não existe proverbiologia. 


\section{Coletaneas de Provérbios}

Da primeira paremiologia publicada no Brasil, dá-nos noticia Raimundo Magalhães Júnior $^{26}$, mencionando o aparecimento no Rio de Janeiro, em 1879, de Provérbios históricos e locuções populares, assinado com o pseudônimo de Teobaldo, baseado, segundo Guilherme Bellegarde, principalmente em Fleurs historiques de Pierre Larousse e L' esprit des autres de Edouard Fournier. Em 1885, surge a primeira edição de Origem de Anexins, prolóquios. locuções populares, siglas, etc. de Antonio de Castro Lopes, com segunda edição em 1909 "E um livro sem base. destituído de mérito, sem abonações, mesmo sem verossimilhança e plausibilidade, no qual o autor se excede em rasgos de imaginação e criação anedóticas, às vezes de péssimo gosto"²7. Em 1908, João Ribeiro publica o primeiro volume do seu famoso Frases feitas, obra básica no estudo da paremiologia juntamente com Tesouro da fraseologia brasileira de Antenor Nascentes, editado pela primeira vez em 1945, com recente terceira edição (1986).

Em Portugal, tem-se como a primeira coletânea de provérbios impressa o trabalho. Adágios portugueses reduzidos a lugares communs pello Lecenciado António Delicado. Prior da Parrochial Igreja de Nossa Senhora da Charidade. termo da Cidade de Évora, natural da vilia de Alvito (Lisboa, 1651), vindo a seguir, o Florilégio do Padre Dom Bento Pereira (Lisboa, 1655). A obra do Pe. Delicado esteve prescrita na Era Pombalina, cento e vinte anos depois de impressa (1771), por conter algumas locuções consideradas irreverentes na época:

- Clérigo que foy frade, nem por amigo nem por compadre,

- Acabo (sic) de cem anos, os Reys sam villoens; e a cabo de cento e dez, os villoens são reys

Ainda em Portugal, dedicaram-se ao estudo da paremiologia François Rolland (Adágios. provérbios, rifãos (sic) e anexins da língua portuguesa, tirados dos melhores Authores Nacionais, e recopilados por ordem alfabética, Lisboa, 1780), Ladislau Batalha, Theophilo Braga, Pedro Chaves, Carolina Michaelis de Vasconcellos, entre outros-28

João Ribeiro dá como o mais antigo provérbio registrado de origem peninsular,

. Lá vão as leis para onde querem os reis

Instituído no reinado de Afonso VI em 1077, por ocasião de um edital que modificava o oficio eclesiástico romano (Quo volunt Reges, vadunt leges) ${ }^{29}$.

Na Franca, as coletâneas mais antigas datam do século XII. Com a invenção da imprensa, tomaram-se populares, sempre em listas por ordem alfabética. Uma das obras mais citadas é Li proverbe au vilain (aproximadamente 1175), composta de curtas histórias de fundo moral, cada uma em estrofes de seis versos, mais o provérbio acompanhado da fórmula de encerramento que se tomou clássica: "assim diz o vilão", ao todo, seis manuscritos com 280 coplas e 285 provérbios. Ainda entre as recolhas mais antigas citam-se o trabalho de Etienne Legris (1140-1144) e Ci commançent proverbes rurauz et vulgauz (cerca de 1317). Alguns autores fixam Leroux de Lincy, o fundador da paremiologia francesa com Proverbes Français $^{30}$ (1859). 
Na Espanha, em 1555, Hernán Nunez de Gusmán em Refranes y proverbios, já faz estudo comparativo. Essa obra tem interessante prólogo escrito pelo discipulo do autor, Leon de Castro, que se desculpa por escrever em romance e diz só ter aceito imcumbir-se do prólogo por estar seu mestre idoso e enfermo. Porém, tem-se como a coletânea espanhola mais antiga - e uma das mais citadas - a obra do Marquês de Santillana, datada entre os séculos XV e XVI, com o pitoresco titulo - Iñigo Lopez de Mendoça a ruego del Rev Don Johann, ordenó estos refranes que dicen las viejas trás el fuego e van ordenados por el $A$. B C. Dessa obra fez-se uma edição em 1852 por D. José Amador dos Rios, com todas as dificuldades inerentes à edição de texto muito antigo Há variantes ortográficas no manuscrito, o que indica ter sido feito sob ditado Os refrães são rimados e metrificados, deles se fizeram muitas glosas, Há referências a Salomão, Platão, Sêneca, Aristóteles, como o fizeram todos os moralizadores de então, porém adaptando-os a moral cristã, às vezes arbitrariamente. A obra não tem um plano, não há divisão temática. Para a época, é considerada democrática; afirma, no conjunto de seus ensinamentos, que há diferenças nas riquezas e culturas, porém não as deve haver na moral; quando se mostram astúcias e injustiças, essas são praticadas pelos nobres entre si. Nesse ponto, trata-se de uma exceção no vasto terreno dos provérbios, que em geral são de moral oportunista e cautelosa.

"El comienço de salut

Es saber

Distinguir e conocer

Quoal esvirtud.

Quien comiença en juventud

A bien obrar,

Seyñal es de no errar

En senetud," 31

A partir do século XIX, de acordo com as paremiologias consultadas, decresceu o interesse em editar coletâneas de provérbios. Nas últimas décadas retornaram à voga, dando inicio a um estudo sistemático à luz das várias correntes da linguística. 


\section{Notas}

1 GUIRAUD, P. 1962, p. 05.

2 PLATÃO. Oeuvres.Traduction nouvelle des notices et des notes para E. Chambry. Paris: Garnier, 1922 (A tradução do francês é nossa).

3 BARROSO, G, 1960. p 83.

4 CORSO, F 1942,p IX

5 CASTRO ALVES, A. “Quem dá aos pobres empresta a Deus". Verso 13-14. In: MAGALHÃES Jr. 1977, p.5.

6 VICTOR HUGO, Chants du crépuscule, In: idem, p. 207.

7 CUNHA, A. C. (1929) p. XIV.

8 FARIA, F. P. (1983) p. 68-74.

9 BATALHA, L. (1924) p. 233-234.

10 HUIZINGA, J. (1980) p. 125-130.

11 Op. cit. p. 125-157.

12 SCHMIDT-RADEFELDT, J. (1984) p. 233-234.

13 BARRETO, M.L.B. (1979) p. 288-295

14 GREIMAS, A . J. (1975) p 288-295.

15 Citado por Leon de Castro, no prólogo de Refranes y proverbios de Hernán Nuñez de Gusmán (1555) In: Corso, F. (1942) p. 30-31.

16 BATALHA, L. (1924) p. 30-31.

17 Op. cit. p. 39.

18 MELLO, F.R. (1974) p.5.

19 SBARDI Y OSUNA, José Maria. Monografía sobre los refranes, adagios y proverbios castellanos etc. Madrid, 1891. In HOYOS SAINZ, L. E NIEVES DE HOYOS, S. (1947) p. 270.

20 CUNHA, A . C. (1929) p. V.

21 Dictionnaire portatif des mots français dont la signification n'est pas familière à tout le monde. In Pineaux, J, (1963) p.5

22 PINEAUX, J. (1963) p. 6.

23 MACHADO FILHO, A . M. (1951) p. 71.

24 Pequena composição poética ordinariamente em quadras, para ser cantada.... In AULETE, F. J. Caldas (1968) p. 943.

25 POTTIER, B. (1973) p.41.

26 MAGALHÃES Jr. , R. (1977) p. 4

27 op. cit. p. 4

28 Informações sobre a história da paremiologia em Portugal foram extraidas de CUNHA, A. (1929)

29 De rebus Hispaniae do arcebispo D. Rodrigo v. VI, p. 25 apud SBARDI Y OSUNA, J. M. v. 8, p. 221. In: RIBEIRO, J. (1960) p. 129 
30 Informações sobre a paremiologia na França foram extraídas de MORAWSKY, J. p. III a XIV

31 MENDOÇA, I. L. (1928) estrofe 16

\section{Referências}

AULETE, Francisco Júlio Caldas. Dicionário contemporâneo da língua portuguesa. 2. ed, brasileira. Rio de janeiro. Deita, 1958, 5v.

BARRETO, Mônica L. de Barros. (org) Do jeito mais simples. Rio de Janeiro, FUNARTE/ SEC, 1979. 2v.

BARROSO, Gustavo, Através dos folclores. São Paulo, Melhoramentos; Rio de Janeiro, Cayeiras /s.d./ 196 p.

BATALHA, Ladislau. História geral dos adágios portugueses. Com estudo preliminar do Dr. Agostinho Fortes. Paris/Lisboa, Livraria Aillaud e Bertrand, 1924, 326 p.

BUYSSENS, Eric. Semiologia e comunicação linguística. Tradução, apresentação e notas de Izidoro Blikstein. 3. ed. São Paulo, Cultrix /s.d./ 217 p.

CÂMARA JR., Joaquim Mattoso Dicionário de fatos gramaticais./s. 1./ MEC/Casa de Rui Barbosa, 1956, 225 p.

CORSO, Felix F. Refranero espanol. Buenos Aires, Libreria Perlado. 1942, 292 p.

COSERIU. Eugênio. Princípios de semântica estructural. Version española de Marcos Martinez Hermández Madrid, Gredos, 1977. 247 p.

CUNHA. Alfredo Carneiro da. Ditames e ditérios; glosas em verso de ditados ou dizeres comuns. Lisboa, Empresa Nacional de Publicidade. 1929. 3v.

CUNHA. António Geraldo da. Dicionário etimológico da língua portuguesa. Rio de Janeiro, Nova Fronteira, 1982. 839 p.

ENCICLOPÉDIA Delta Larousse. 2. ed. Rio de Janeiro, Delta /s.d./ 15 v. il.

FARIA, Flora de Paoli. A estruturação do regionalismo em Giovanni Verga, dissertação de Mestrado em Teoria Literária, na UFRJ, em 1983. fl.68-69 e fl.74.

FERREIRA. Aurélio Buarque de Holanda. Novo dicionário da língua portuguesa- la. ed. RJ, Nova Fronteira, 1975, 1517 p.

GOTTSCHALK, Walter. Die bildhaften Sprichwörter der Romanen. Heideiberg, CarlWinters Universitätsbuchhandlung, 1935-1938. 3v.

GREIMAS. Algirdas Julien. “Idiotismes, proverbes et dictons.” Cahiers de lexicologie. Paris, Didier Larousse (v.2) : 41-62, 1960.

“Os provérbios e os ditados. "Sobre o sentido - ensaios semióticos. Tradução de Ana Cristina Cruz e outros, Petrópolis. Vozes, 1975. p. 288-295.

GUIRAUD, Pierre. Les locutions françaises. Paris, Presses Universitaires de France, 1962, $122 \mathrm{p}$.

HOYOS SAINZ, Luiz de e NIEVES de HOYOS, Sancho. Manual de folclore. Manuales de la revista de ocidente. Madrid/s.d./ 1947. p. 263-270. 
HUIZINGA. Johan. Homo ludens, 2. ed. São Paulo, Perspectiva, 1980, 242 p-.

KLEIN, Hans Wilhelm, Die volkstümlichen sprichwõrtlichen Vergleiche im Lateinischen und in den romanischen Sprachen. Un. Tübingen, 1936.98 p-

LOPES, Antonio de Castro. Origem dos anexins. prulóquios. locuções populares, siglas, etc. Riu de Janeiro, Cia. impressora, Í893. 251 pmentário, ! 977.330 p.

MACHADO FILHO, Aires da Mata, Curso de folclore. Rio de Janeiro, Livros de Portugal, 1951. p. 71-76.

MAGAlHÃES JR. Raimundo. Dicionário brasileiro de provérbios, locuções e ditos curiosos. 4, ed, Rio de Janeiro, Documentário, 1977. 330 p.

MELLO, Fernando Ribeiro de. Nova recolha de provérbios e outros lugares comuns portugueses. Lisboa, Afrodite, 1974, 385 p.

MENDOÇA, Iñigo Lopez de. Marquês de Santillana. Los provérbios de ......... Prólogo de D. José Rogério Sanchez. Segundo o códice N. J. 13 de El Escorial, Madrid, Libreria general de Victoriano Suarez, 1928. 123 p. il.

MORAWSKY, Joseph. Proverbes francais anterieurs au Xve. siècle. Librairie Ancienne Edouard Champion Editeur, 1925. 146 p.

MOTA, Leonardo. Adagiário brasileiro, Fortaleza, Edições Universidade Federal do Ceará; Rio de Janeiro, J. OIyrnpio, 1982. 433 p.

NASCENTES, Antenor. Dicionário etimológico da língua portuguesa. Rio de Janeiro, /s.Ed./ 1932. 2v.

. Tesouro da fraseologia brasileira. 3.ed. rev. por Olavo Aníbal Nascentes. Rio de Janeiro, Nova Fronteira, 1936, 431 p,

PINEAUX. J. Proverbes et dictons français. Paris. Presses Universitaires de France. 1963. $128 \mathrm{p}$,

PINTO, Alexina de Magalhães. Provérbios populares, máximas e observações casuais. Colleção ICKS, Série F/ s.1. /s.Ed./ 1917. p. 12-21.

POTTIER, Bernard, dir. Le langage. Les dictionaires du savoír moderne. Paris, Centre d'Etude et de Promotion de Ia lecture, 1973, 544 p.

Linguistica geral. Teoria e descrição. Tradução e adaptação portuguesa de Walmirio Macedo. Rio de Janeiro, Universidade Santa Úrsula, 1978, p, 269-270.

RIBEIRO, João. Frases feitas. 2. ed. org. por Joaquim Ribeiro. RJ, Francisco Alves, 1960. $432 \mathrm{p}$.

SCHMIDT-RADEFELDT, Jürgen, "Descrição semântica e funções semanfóricas do provérbio". Estudos de linguística portuguesa. Coimbra Editora, 1984, p. 213-235.

"Structure argumentative et contextualité du proverbe." Stylistique, rhetorique et poétique dans les langues romanes. Actes du XV11 Congrès International de Linguistique et Philologie Romanes. Aix-en-Provence. 1983. p. 88-102.

SILVA, António de Moraes. Diccionário da língua portugueza, recopilado dos vocabulários impressos até agora e nesta segunda edição novamente emendado e muito acrescentado. Lisboa, Typografía Lacérdina, 1813. Edição photographada pela "Revista de Língua Portuguesa" sob a direção de Laudelino Freire, Rio de Janeiro 1922. 2v. 
SILVA, Helena Maria Quintão Duarte e QUINTAO, José Luís, Pequeno dicionário de provérbios, Lisboa Editores, 1983, 163 p.

STEINBERG, Martha. 1001 provérbios em contraste. São Paulo. Ática. 1985.127 p.

ULLMANN. Stephen. Semântica: uma introdução à ciência do significado. Tradução de J. A. Osório Mateus, 2. ed. Fundação Calouste Gulbenkian, Lisboa, 1964. 577 p.

ZUMTHOR, Paul, "L'epiphonème proverbial." Révue des sciences humaines. Lille, 1976. p. 316-328 